\title{
Official development assistance, social capital and growth in Latin America
}

\author{
Isabel Neira, Maricruz Lacalle-Calderón and Marta Portela
}

ABSTRACT

This study focuses on the relationship among official development assistance (ODA), social capital and economic growth in Latin American countries, attempting to determine whether the impact of such assistance on growth is conditional on the receiving country's stock of social capital. To this end, we use "trust" to measure social capital in an unbalanced panel of 18 Latin American countries over the period 2001-2010. After accounting for country and time effects in a dynamic panel data model, our results show that the impact of ODA on growth is indeed conditional on the level of trust that exists. This suggests that this assistance will be more effective when used in a trust-rich environment.

KEYWORDS

JEL CLASSIFICATION

AUTHORS
Economic development, development assistance, economic growth, social capital, econometric models, Latin America

C230, F350, O200, O400

Isabel Neira is an associate professor in the Econometrics Department of the School of Economics and Business of the University of Santiago de Compostela, Spain. isabel.neira@usc.es

Maricruz Lacalle-Calderón is an associate researcher in the Applied Economics Department of the School of Economics of the Universidad Autónoma de Madrid, Spain. maicu.lacalle@uam.es

Marta Portela is a senior lecturer in the Department of Finance and Accounting of the School of Business of the University of Santiago de Compostela, Spain. marta.portela@usc.es 


\section{I}

\section{Introduction}

The effectiveness of official development assistance (ODA) has been the subject of numerous empirical studies. However, the impact it is expected to have on growth in receiving countries continues to be an object of debate (Easterly, 2008; Gibson and others, 2009).

Several of these studies have also looked at other factors, such as institutions or social relationships, that may have an impact on the effectiveness of ODA and hence could indirectly promote or hinder the growth process. For example, Burnside and Dollar (2000) find that the potential for ODA to have a positive impact on growth depends on the presence of sound fiscal, monetary and trade policies. Kaufmann, Kraay and Zoido-Lobatón (1999) propose six indicators of governance that they believe can function as important ODA selection criteria. Rivera-Batiz (2002) notes that governance-improving democracy increases growth by reducing corruption. Choritz (2002), Simon and McGillivray (2003) and Knack (2001) find that a better understanding of the region's existing social capital and other drivers of growth needs to be achieved prior to the implementation of development policies and projects. Baliamoune-Lutz and Mavrotas (2009) study whether social capital and institutions enhance the effectiveness of ODA. Apart from this last paper, which suffers from some limitations, the literature does not provide any other empirical evidence regarding the macroeconomic effect of social capital on the effectiveness of ODA. ${ }^{1}$

An application of the basic two-gap model (Chenery and Strout, 1966) indicates that ODA is required in order to close the savings-investment gap in poor countries. Therefore, when aid is used to finance productive investment, it can be expected to have a positive impact on growth. However, the decision to use oDA for productive investment, along with its subsequent effect on growth, may be influenced by the levels or quality of a given country's social capital.

Following Burnside and Dollar (2000) and Baliamoune-Lutz and Mavrotas (2009), this study looks at

\footnotetext{
1 Other authors, such as Knowles (2007), have studied the effect of social capital on the allocation of aid; this area of inquiry is beyond the scope of this paper, however.
}

whether the impact of ODA on growth is conditional on the receiving country's institutional and social environment, which can be - and has been - measured on the basis of such variables as good governance, democracy or social capital. An effort is made to test the hypothesis that the impact of ODA on growth in Latin America is conditional on the existing stock of social capital, with "trust" used as the most accurate proxy for this variable. An estimation procedure that is superior to ordinary least square (OLS) is employed for this purpose. The present study thus contributes to the literature by exploring the interaction between ODA and social capital (measured by trust) as a determinant of GDP growth.

Using a modified neoclassical growth model, we empirically study the effectiveness of ODA in the presence of trust based on an analysis of an unbalanced panel of 18 Latin American countries ${ }^{3}$ during the period 2001-2010. The results show that ODA has a positive and statistically significant effect on growth in a trust-rich environment, but has no effect in its absence.

The rest of this paper is organized as follows. Section II summarizes the most important literature on the effectiveness of ODA in driving growth. In section III, trust is analysed as a form of social capital, and an effort is made to determine how it may condition the effectiveness of ODA. Section IV presents the data and the panel data model used to explore the dynamics of ODA, trust and the impact of their interaction on economic growth. Section V presents a discussion of the results of the comparison of the effectiveness of ODA in the presence and absence of trust. Section VI concludes.

\footnotetext{
2 Following the recent literature, trust is probably the most accurate proxy for measuring social capital (Knack and Keefer ,1997; Whiteley, 2000; Beugelsdijk and Van Schaik, 2005; Helliwell and Putnam, 2000; Temple, 2001; Dollar and Kraay, 2002; Neira, Vázquez and Portela, 2009).

${ }^{3}$ Specifically: Argentina, the Bolivarian Republic of Venezuela, Brazil, Chile, Colombia, Costa Rica, the Dominican Republic, Ecuador, El Salvador, Guatemala, Honduras, Mexico, Nicaragua, Panama, Paraguay, Peru, the Plurinational State of Bolivia, and Uruguay.
} 


\section{II \\ Official development assistance and economic growth}

Several recent empirical studies have sought to determine whether or not ODA has a macroeconomic impact on growth. Two main but opposing positions on the effectiveness of aid can be defined, although the evidence is still ambiguous and the debate continues (Easterly, 2008; Sachs, 2011).

In the aftermath of the Second World War, ODA emerged as an imperative, since external financial flows were necessary in order to reduce the internal and external gaps existing in the economies of poor countries (Chenery and Strout, 1966). In the decades that followed, a determined research effort was made to demonstrate the effectiveness of ODA in driving growth. Some studies obtained positive results (Levy, 1988), but in others the results were clearly negative (Mosley, Hudson and Horrel, 1987; Mosley, 1980; Boone, 1996). Many of these studies did not treat the endogeneity of ODA, which may account for their contradictory results (Arndt, Jones and Tarp, 2010). Then, in a study conducted in 2000, Burnside and Dollar (2000) found that ODA "works" in "good policy environments." The belief that ODA boosts economic growth, reduces poverty and improves social indicators within good policy environments led the World Bank to increase its ODA budgets worldwide (Easterly, 2003).

Since the appearance of Burnside's and Dollar's paper (2000), several studies have produced contrasting results. Hansen and Tarp (2000 and 2001), Dalgaard and Hansen
(2001), Lensink and White (2001) and Clemens and others (2012) find a positive causal relationship between aid and economic growth that is not conditional on a good policy environment or high-quality institutions, as their results indicate that ODA spurs growth even in countries hampered by an unfavourable policy environment. In contrast, several other studies have found that ODA has no effect on growth, whether or not there is a sound policy environment (Easterly, 2003; Easterly, Levine and Roodman, 2004; Rajan and Subramanian, 2008). These authors contend that neither short-impact aid nor any other type of assistance has positive effects on growth. Moreover, they also find no difference between the growth impact of bilateral and multilateral aid. Djankov, Montalvo and Reynal-Querol (2006 and 2008) find that ODA has a negative impact on democracy and economic growth in developing countries. The main problems faced by these authors when attempting to gauge the impact of ODA on growth have been the erratic nature of such assistance, poor data quality, the low ratio of ODA to GDP in most recipient countries, endogeneity problems and the use of weak instruments (Tarp, 2006).

Two recent meta-analyses provide contrasting results. Doucouliagos and Paldam (2011) find that ODA is ineffective in promoting growth, while Mekasha and Tarp (2013) find that its effect on growth is positive and statistically significant. An extensive review of the literature demonstrates that the debate continues.

\section{III}

\section{Social capital, official development assistance and economic growth}

Social capital is not homogenous; its nature and the forms it takes change over time depending on the type of balance that exists between public and private organizations and on the situation in the particular country concerned. There are many different definitions of social capital, since the concept is relevant to numerous disciplines, including sociology, political science, economics and many others. Most of these definitions use terms such as "networks," "trust" and "rules" or "norms." One of the aphorisms frequently used to describe social capital is "It's not what you know, it's who you know." According to Coleman (1988 and 2000), social capital is anything 
that facilitates individual or collective action and is generated by networks of relationships, reciprocity, trust and social norms. This definition of social capital is close to Bourdieu's (1986) and Loury's (1977). For Coleman (1988), social capital can be described as a neutral resource derived from the social structure that facilitates certain actions on the part of individuals or corporate actors, thereby allowing the achievement of certain ends which, in the absence of social capital, would not be attainable.

From a political viewpoint, Putnam (1995) describes social capital as "features of social organization, such as networks, norms and trust, which facilitate coordination and cooperation for mutual benefit." The definitions proposed by the Organization for Economic Cooperation and Development (OECD) and the World Bank are similar. The former states that social capital includes the "networks, norms, values and understandings that facilitate cooperation within or among groups" (OECD, 2001). In turn, the World Bank defines social capital as the institutions, relationships and norms that shape the quality and quantity of a society's social interactions (World Bank, 1985). Therefore, the expression of a relationship, a link between trust or confidence and civic cooperation, is inherent in the idea of social capital. Social capital is the result of a process of dynamic interaction. It must be created. It can be increased or destroyed, either deliberately or not, and requires ongoing investment. Hence, for all these reasons, social capital should be considered just that: a form of capital. The most important contributions to this body of thought are summarized in table 1.

TABLE 1

Definitions of social capital

\begin{tabular}{lll}
\hline Author & Generating elements & Consequences \\
\hline Bourdieu (1985) & Permanent networks and membership in a group & Assuring members of a set of current or potential resources \\
\hline Coleman (1988) & Aspects of social structure & $\begin{array}{l}\text { Facilitating certain common actions on the part of agents } \\
\text { within the structure }\end{array}$ \\
\hline $\begin{array}{l}\text { Putnam, Leonardi } \\
\text { and Nanetti (1993) }\end{array}$ & $\begin{array}{l}\text { Aspects of social organizations such as networks, } \\
\text { norms and confidence }\end{array}$ & Facilitating action and cooperation for mutual benefit \\
\hline World Bank (1998) & Institutions, relationships and norms & $\begin{array}{l}\text { Shaping the quality and quantity of a society's } \\
\text { social interactions }\end{array}$ \\
\hline OECD (2001) & $\begin{array}{l}\text { Networks together with norms, values and shared } \\
\text { opinions }\end{array}$ & Facilitating cooperation within and among groups \\
\hline ECLAC (2002) & $\begin{array}{l}\text { Social capital is a society's set of norms, institutions } \\
\text { and organizations }\end{array}$ & $\begin{array}{l}\text { Promoting confidence and cooperation among people, } \\
\text { communities and society as a whole }\end{array}$ \\
\hline $\begin{array}{l}\text { Social Capital } \\
\text { Interest Group } \\
\text { (sCIG) (1999) }\end{array}$ & $\begin{array}{l}\text { The potential benefits, advantages and preferential } \\
\text { treatment that arise as the result of compassion and } \\
\text { the sense of obligation that a person feels towards } \\
\text { a group or the group feels towards another person }\end{array}$ & $\begin{array}{l}\text { Including the potential benefits, advantages and preferential } \\
\text { treatment that originate from one person's sympathy and } \\
\text { sense of obligation towards his or her idealized self }\end{array}$ \\
\hline
\end{tabular}

Source: I. Neira, E. Vázquez and M. Portela, "An empirical analysis of social capital and economic growth in Europe (1980-2000)", Social Indicators Research, vol. 92, No. 1, Springer, 2009.

Note: SCIG is affiliated with the University of Michigan.

In an effort to measure social capital, empirical studies have used a range of different variables to attempt to capture this elusive concept and its multiple dimensions (Durlauf, 2002; Bjørnskov, 2006). However, Oorschot and Arts (2005) note that there is a growing consensus that the empirical indicators of social capital can be grouped into three broad dimensions based on the above definitions. The first is social trust, which is the most frequently used variable in the empirical literature on social capital (Knack and Keefer, 1997; Whiteley, 2000; Beugelsdijk, De Groot and Van Schaik,
2004; Helliwell and Putnam, 2000; Temple, 2001; Dollar and Kraay, 2002). Social trust usually involves different types of trust or confidence, ranging from confidence in family members, neighbours, the country's population and so forth. This first dimension is the variable that we have chosen to measure social capital in this paper. The second variable is social networks, which is often used to measure participation in various associations in an attempt to assess the social integration of the members of the community being analysed (Helliwell, 1996; Knack and Keefer, 1997; Beugelsdijk and Van Schaik, 
2005; Hall, 1999). The third dimension, social norms, is employed to analyse shared norms and civic values as reflected in such variables as the level of corruption, the degree of democracy, crime rates, divorce, levels of unemployment and so forth (Putnam, 2000; Bartolini and Bonatti, 2008).

There are several studies that have sought to determine whether a greater degree of social capital is always positively related to economic development and whether the different stages of development require different mixes of social capital. It is also possible that, at certain times or in particular societies, there may be particular forms of antagonistic social capital. Some authors advance the idea that social capital has a negative effect on society. The excessive religious fervour with which certain countries run their societies can result in wars or the onset of other kinds of conflicts, and membership in zealous groups of that type may have negative effects. Fukuyama (1999) states that: "Both the Ku Klux Klan and the Mafia achieve cooperative ends on the basis of shared norms, and therefore have social capital, but they also produce abundant negative externalities for the larger society in which they are embedded." However, although some networks may have a negative impact if they focus on themselves to the detriment of society at large, trust relationships are generally assumed to be positive factors in terms of social cohesion and economic success (Beugelsdijk, De Groot and Van Schaik, 2004; Beugelsdijk and Van Schaik, 2005; Helliwell and Putnam, 2000; Neira, Vázquez and Portela, 2009). The presence of social capital (measured by trust) within social structures can enhance many activities and make them less costly, thereby furthering the development process. Such activities include collective decision-making, the coordination of different actions, the spread of innovation and so forth. In the presence of social capital, these activities are conducted more efficiently because, in a context marked by trust and the pursuit of common goals, people are more willing to cooperate with one another (Knack and Keefer, 1997; Fukuyama, 2001; Adler and Kwon, 2002).

The literature does not, however, offer any empirical studies dealing with the question of how trust, as a form of social capital, may enhance the effectiveness of ODA in driving growth. ${ }^{4}$ From the perspective of the countries

\footnotetext{
${ }^{4}$ To the best of our knowledge, only Baliamoune-Lutz and Mavrotas (2009) have undertaken a study of this type, but they did not use trust as a proxy for social capital. Instead, they used ethno-linguistic fractionalization as a proxy for social cohesion and social cohesion as a major indicator of social capital.
}

receiving ODA, we can posit three basic ways in which trust may alter the effectiveness of ODA and therefore influence these countries' economic growth paths.

First of all, trust reduces transaction costs and facilitates the flow of information. Since the foreign aid system is extremely fragmented (Easterly, 2008), a trust-rich environment in the recipient country will engender coordination within the system, collaboration among agents, consensus on specific and global objectives and communication, all of which will help to ensure that scarce resources are employed where they are most needed. A transparent bureaucracy and the existence of mechanisms for promoting dialogue and resolving conflicts are necessary conditions for the successful use of ODA. By contrast, in the absence of trust, agents will probably work towards contradictory goals or will duplicate objectives and tasks.

Second, trust reduces opportunistic behaviour. In contexts marked by low levels of trust, there is a risk that cooperation will be of a sort that will benefit the wealthiest members of the recipient societies or the most selfish ones who have no regard for their compatriots. A trust-rich environment is crucial in order for ODA to be channeled into productive investments benefiting the most vulnerable populations. Trust between donor and recipient countries and between recipient governments and civil society is of pivotal importance because a proper use of ODA requires the combination of different forms of knowledge that are embedded in all the various types of social agents.

Third, trust paves the way for a sense of ownership on the part of recipients, and without that kind of ownership, recipient countries will not make the commitments needed to ensure the optimal progress of development projects (Gibson and others, 2009). Such projects should be coupled with local ownership of the corresponding funds. Knack (2001) and Dollar and Pritchett (1998) point to the need to emphasize the role of citizens' participation and social capital in recipient countries in ensuring that the foreign aid system will be effective. For all these reasons, it can be assumed that trust has a positive effect on the effectiveness of ODA in driving growth.

The literature on the effectiveness of ODA in promoting growth includes several studies dealing with factors other than social capital that relate to the quality of the receiving country's institutional structure. These factors include good governance, good policies and a democratic environment. Dollar and Pritchett (1998) note that development assistance bolsters economic growth and helps to reduce poverty if local governments are good managers of their social, political and economic 
institutions. Burnside and Dollar (2000) find that, in order for ODA to be effective, better fiscal, monetary and trade policymaking practices in recipient countries are needed. Kaufmann, Kraay and Zoido-Lobatón (1999) propose six indicators of good governance that they believe can function as important development assistance selection criteria. In addition, Rivera-Batiz (2002) notes that governance-improving democracy boosts growth by reducing corruption.

The "good policies" premise has shaped the ODA policies developed over the last decade; however, some authors, such as Baliamoune-Lutz and Mavrotas (2009), contend that they are not a key determinant and that factors such as social capital are more important in determining whether ODA is used successfully or not. Along these lines, Choritz (2002), Simon and McGillivray (2003), Knack (2001) and Baliamoune-Lutz and Mavrotas (2009) highlight the need for a better understanding of the social capital existing in a recipient region before the authorities begin to formulate policies or design development projects. In other words, the existing stock of social capital in a region has to be identified in advance because it may leverage or hinder the effectiveness of ODA in furthering the growth process.

\section{IV}

\section{Empirical analysis}

Studies of the effect of ODA on growth are generally based on a sample of countries around the world and use specific dummies for different continents. Our sample of 18 Latin American countries is used to study the role of trust in determining the effectiveness of ODA in this geographical area. Accurate data on the influence exerted by social capital on ODA recipient countries are generally quite limited; however, in the case of Latin America, which is a major ODA recipient, the Latinobarómetro database provides very good data on trust, which is the proxy used for social capital in this study.

\section{Data}

The dataset used to analyse the impact of trust on ODA effectiveness was obtained by combining several sources (see annex table A.1). The variable records were matched by country and year. After excluding some records that could not be matched, we obtained a final dataset composed of an unbalanced panel of 18 countries over the period 2001-2010.

The dependent variable is economic growth ${ }^{5}$ as measured by the log of real GDP purchasing power parity (PPP) $\left(L_{0} g_{G} G D P_{i t}\right)$ derived from the World Development Indicators (World Bank, 2014). The main explanatory variables are ODA (Log_ODA), measured as the log of total net ODA (OECD, 2013), and TRUST (trust), measured

\footnotetext{
${ }^{5}$ Since we are using the generalized method of moments (GMM), the estimated dependent variable is economic growth. GMM uses variables in differences (see equation (2)) but, given that the variables are in logarithmic form, their differences become rates of growth for the original variables in levels (Acemoglu and others, 2008).
}

as the percentage of people who answered that "You can trust most people" in response to the question "Generally speaking, would you say that you can trust most people, or that you can never be too careful when dealing with others?"(Latinobarómetro, 2010). Other variables that are used in the literature as explanatory variables for growth and that are included in our model are: population (Log_popu), measured by the log of the total number of people in the country; employment (employment), measured by the proportion of a country's total population (aged 15 years and older) that is employed; and investment (Log_gcf), which is measured by the log of gross capital formation. The figures for all three of these variables are drawn from the World Development Indicators database (World Bank, 2014). The education $(e d u)$ variable, measured by total years of schooling, is derived from Barro and Lee (2012). Following Acemoglu and others (2008) and Burnside and Dollar (2000), we also introduce the country's level of democracy (democ) as a control variable (taken from Polity IV, 2013), since we consider democracy to be a separate variable that is independent of social capital.

Map 1 and figure 1 illustrate the levels of net ODA received by each country during the period under study. Maps 2 and 3 show the average levels of trust and democracy in each country for the selected years. Since the net amount of ODA received by each country changes significantly from year to year within our study period, we have depicted these data in map 1 and figure 1 . In the case of trust and democracy, since these data are very stable between and within countries, we have simply mapped the average values for the period 2001-2010. 
MAP 1

Latin America: net official development assistance (ODA) received by each country, 2001-2010

(Billions of dollars)

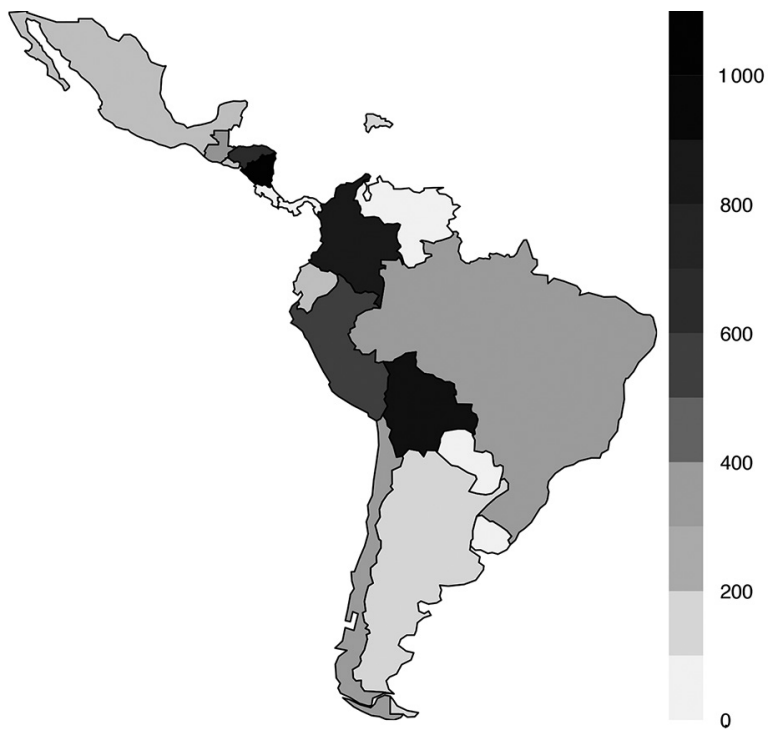

Source: Prepared by the authors, on the basis of the Organization for Economic Cooperation and Development (OECD) database (average for selected years).

Note: The boundaries shown on this map do not imply official endorsement or acceptance by the United Nations.

MAP 2

\section{Latin America: trust levels in each country, ${ }^{a}$ average for selected years between 2001 and 2010}

(Percentages)

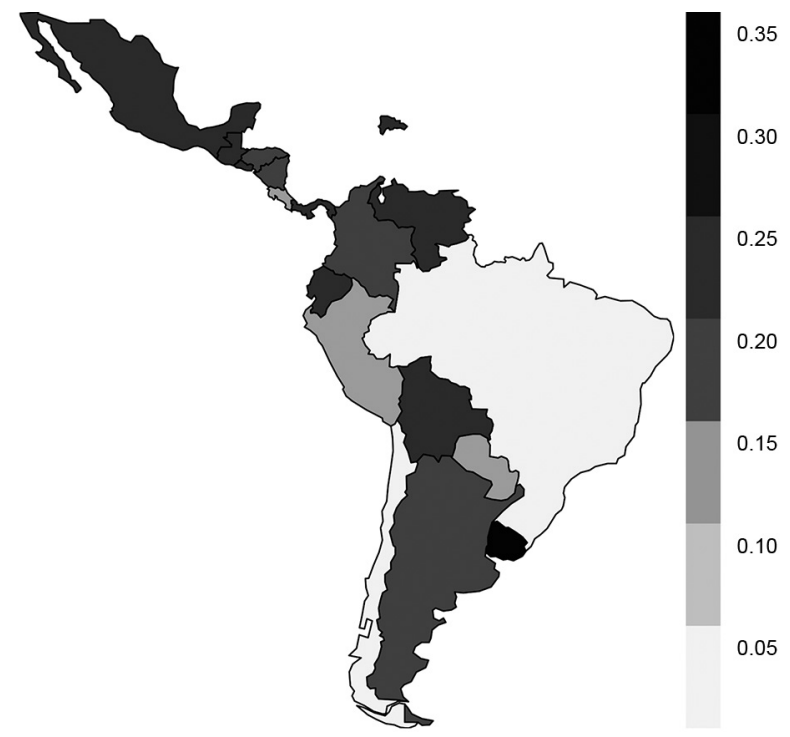

Source: Prepared by the authors, on the basis of Latinobarómetro (2010) database.

Note: The boundaries shown on this map do not imply official endorsement or acceptance by the United Nations.

a Percentage of persons replying "You can trust most people" to the question "Generally speaking, would you say that you can trust most people, or that you can never be too careful when dealing with others?" 
All the countries in our sample are oDA recipients and, as can be seen in map 1 and figure 1, Haiti and Nicaragua are the main recipients that experienced major changes in the volumes of ODA received from year to year. Other countries receiving large amounts of ODA include the Plurinational State of Bolivia, Honduras and Colombia. On the other hand, the Bolivarian Republic of Venezuela, Uruguay, Costa Rica and Paraguay received the smallest net ODA volumes.

MAP 3

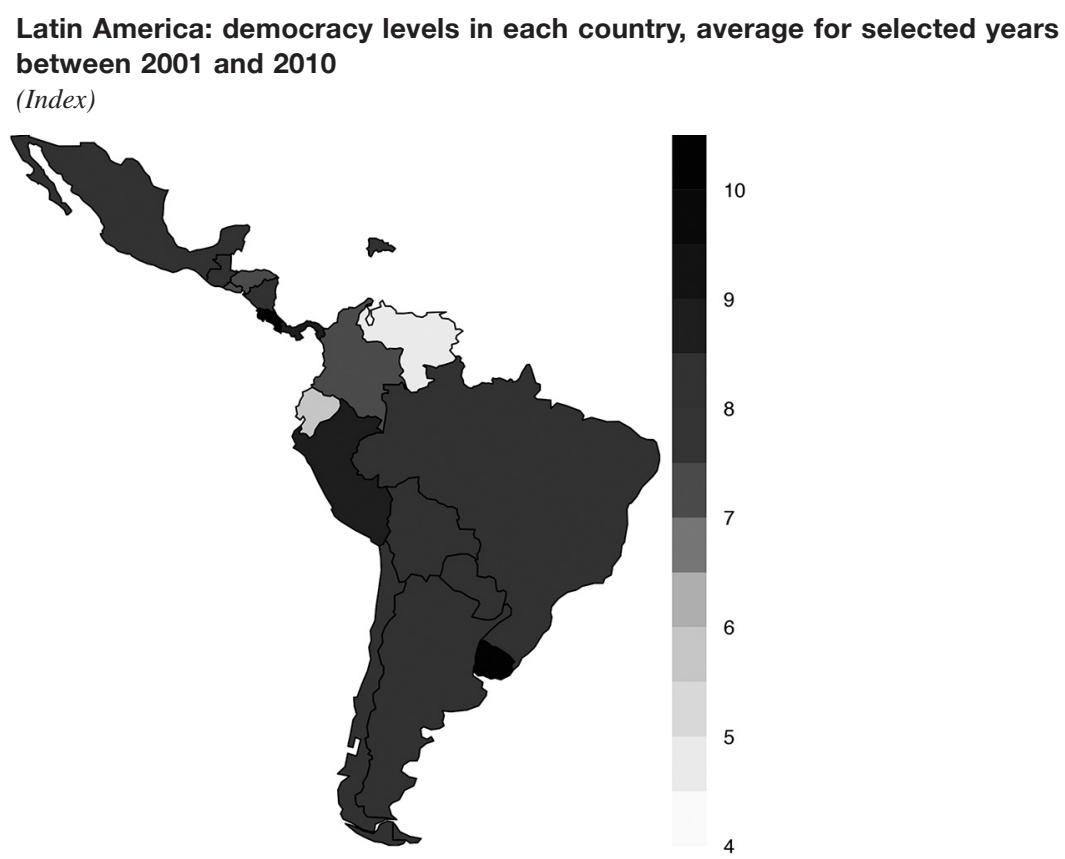

Source: Prepared by the authors, on the basis of Polity IV (2013) project database.

Note: The boundaries shown on this map do not imply official endorsement or acceptance by the United Nations.

Trust levels in all the countries in our sample are low. Only $18 \%$ to $32 \%$ of the population in these countries responded that "You can trust most people" when they were asked "Generally speaking, would you say that you can trust most people, or that you can never be too careful when dealing with others?" The countries with the highest values are the Dominican Republic, Uruguay, Mexico and Guatemala. The countries with the lowest values are the Bolivarian Republic of Venezuela, Argentina, Honduras and the Plurinational State of Bolivia.

The democracy data take integer values ranging from 1 (absolute lack of democracy) to 10 (the highest level of democracy). In this case, Ecuador, the Bolivarian Republic of Venezuela, Haiti and Honduras are the countries with the highest coefficients, while Argentina, Guatemala, Brazil and the Dominican Republic have the lowest. Therefore, the correlation of the data on trust and democracy is low. In countries where trust levels are high, the level of democracy may be low, medium or high.

Annex table A.2 provides descriptive statistics for all the variables in the regressions. In each case, we report means and standard deviations, along with the total number of countries for which we have data and the total number of observations. Annex table A.3 presents the correlations among the different variables.

\section{Estimation procedure}

The following analytical model, which is a modified neoclassical model, has been the basis for our work:

$$
y_{i t}=\alpha+\lambda y_{i t-1}+\beta_{i} x_{i t}^{\prime}+\delta_{i}+\omega_{t}+\varepsilon_{i t}
$$

where the lagged value of $\log \operatorname{GDP}\left(\log _{-} G D P_{i, t-1}\right)$ is used to control for persistence of economic growth over time, 
FIGURE 1

Latin America: net official development assistance (ODA) received by each country, 1996-2001

(Billions of dollars)
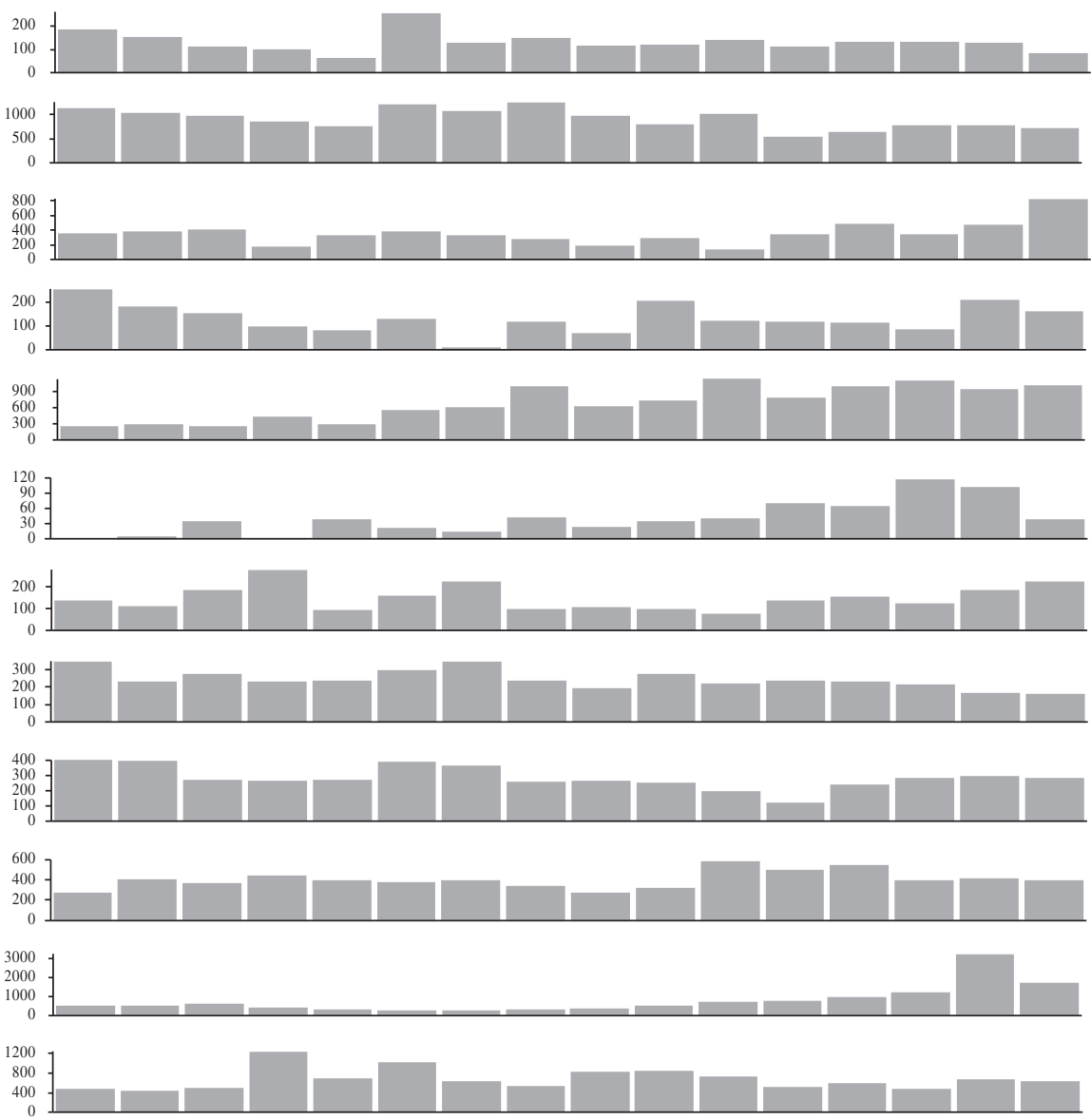

Guatemala

Haiti

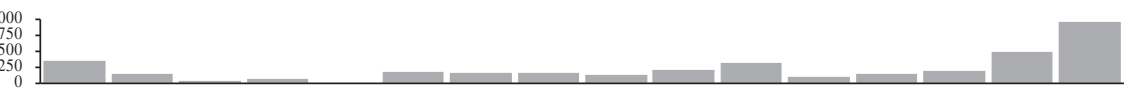

Honduras

Mexico
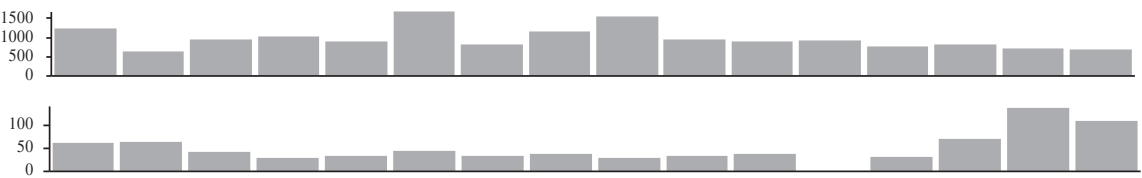

Nicaragua

Panama

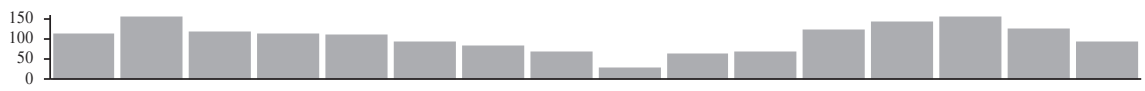

Paraguay

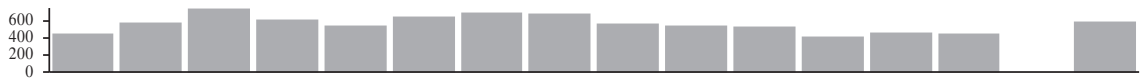

Peru

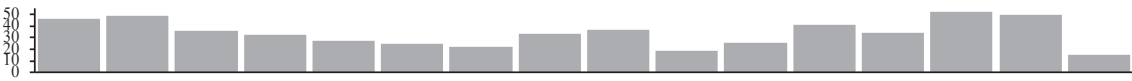

Uruguay

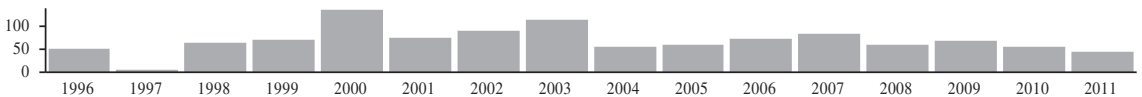

Venezuela (Bol. Rep. of)

Source: Prepared by the authors, on the basis of the database of the Organization for Economic Cooperation and Development (OECD). 
while $X_{i t}^{\prime}$ includes ODA and trust, our main independent variables; a group of control variables is also included in the main growth models (education, population, employment, investment and democracy). In addition, $X_{i t}^{\prime}$ contains the interaction term "Log_ODA*trust" to contrast our hypothesis that ODA effectiveness is conditional on the level of social capital in the country; it also includes the interaction term "Log_ODA*democ" in order to compare the different social and institutional measures. The terms $\delta_{i}$ and $\omega_{t}$ capture unobservable time and country heterogeneity, since we allow for the presence of country effects; $\alpha$ and $\beta$ are the parameters to be estimated; and $\varepsilon_{i t}$ is the error term, capturing all other omitted factors, and $\mathrm{E}\left[\varepsilon_{i t}\right]=0$ for all $\mathrm{i}$ and $\mathrm{t}$.

In line with the procedure used in Asiedu and Nandwa (2007), we estimate the equation based on the work of Hansen and Tarp (2001), who analysed several ODA regressions to highlight the fact that ODA variables cannot be exogenous to growth regressions. This implies that alternatives to ols estimates are required. Equation (2) is the specification of a dynamic panel data model of the logarithm of real GDP $\left(\log _{-} G D P_{i t}\right)$,

$$
\Delta y_{i t}=\alpha+\lambda \Delta y_{i t-1}+\beta_{i} \Delta x_{i t}^{\prime}+\Delta \varepsilon_{i t}
$$

We estimate equation (2), a dynamic panel data model, using the consistent GMM proposed by Arellano and Bond (1991). This method allows for unobserved country-specific effects, measurement errors and

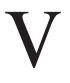

\section{Results}

The estimation results of the models in equations (1) and (2) are presented in table 2 . The reader will recall that our aim is to determine whether the effectiveness of ODA in promoting growth is conditioned by the level of trust existing in the country concerned.

The Arellano-Bond (1991) serial autocorrelation tests have the expected outcomes in all cases except for model 1, which was included in order to test the robustness of the results. These test results are always significant for a first-order autocorrelation $(t-1)$, but not significant for the second-order autocorrelation. The Sargan specification test always accepts the null hypothesis of validity of the over-identifying restrictions, endogeneity problems, not only in the case of the lagged dependent variable but also of any other regressor (Arndt, Jones and Tarp, 2010). The main theoretical reason for using the dynamic panel is that it is modelling a partial adjustment-based approach. If we are dealing with a partial adjustment process, then the coefficient on the lagged dependent variable measures the speed of adjustment. In addition, the lagged dependent variable can remove any autocorrelation.

In order to treat endogeneity, Arellano's and Bond's (1991) "difference GMM" estimator uses the lagged levels of first difference of the variables as instruments for both the lagged dependent variable and the other explanatory variables. This method identifies the number of lags of the dependent variable, the predetermined variables and the endogenous variables as valid instruments and shows how to combine these lagged levels with the first differences of the strictly exogenous variables into a potentially large instrument matrix. We employ the so-called "two-step" difference GMM estimator, which allows for heteroskedasticity in the error terms. Arellano's and Bond's model assumes that when $x_{i t}$ and $\varepsilon_{i t}$ are not serially correlated, this hypothesis can be contrasted using the $\mathrm{m} 2$ statistic tests to analyse the second-order serial correlation in the first-difference residuals. Specification tests are applicable in this context. One such test is the Sargan test for over-identifying restrictions (Sargan, 1958). The results of this test indicate that it is not necessary to consider other instruments.

indicating that the specification of both the model and instruments is good.

The results displayed in table 2 show coefficient estimates with the expected signs. The results are always statistically significant.

The results reported in table 2 reflect four main findings. First of all, there is a negative and significant relationship between ODA and economic growth, and this result is consistent in all our specifications. Even when controlling for trust (model 1) or for the interaction term "Log_ODA*trust" (model 2) or for democracy (model 4) or for the interaction term "Log_ODA*democ" (model 5), the effect of ODA on growth remains negative. These 
results are similar to those obtained by Boone (1996), Easterly (2003), Rajan and Subramanian (2008) and Djankov, Montalvo and Reynal-Querol (2006 and 2008), who find that ODA has a negative impact on economic growth in developing countries.

Second, trust, as a form of social capital, is positive for the effectiveness of ODA in driving growth. Model (1) in table 2 indicates that trust, on its own, is an important explanatory factor for growth. The results in columns 2 and 3 are interesting. ODA has a positive and statistically significant effect on growth in trust-rich environments; however, if the interaction between aid and trust is omitted, ODA no longer has a positive effect on growth. It is also interesting that the estimated coefficient for the interaction of trust and ODA remains positive even when ODA is excluded from the regressions. All this means that the impact of oDA on growth is consistently greater in a trust-rich environment than in a trust-poor one. These results are consistent with those of Burnside and Dollar (2000) in showing that the effectiveness of ODA is conditional upon other variables (fiscal, monetary and trade policies) and, in our study, also on social capital. They are also consistent with Baliamoune-Lutz and Mavrotas (2009), who find that, when ODA is interacted with social cohesion, the result is a significantly positive coefficient.

TABLE 2

Estimation results for an 18-country sample, 2001-2010

\begin{tabular}{|c|c|c|c|c|c|c|c|}
\hline \multirow{2}{*}{\multicolumn{2}{|c|}{$\begin{array}{l}\text { Dependent variable: } \\
\text { Independent variables: }\end{array}$}} & \multicolumn{6}{|c|}{$\log G D P$} \\
\hline & & (1) & (2) & (3) & (4) & (5) & (6) \\
\hline $\log O D A$ & & $-0.0064 * * *$ & $-0.0074 * * *$ & & $-0.0094 * * *$ & $-0.0095 * * *$ & \\
\hline Trust & & $0.0788 * * *$ & & & - & - & \\
\hline Lagged dependent variable & & $0.5409 * * *$ & $0.5109 * * *$ & $0.5263 * * *$ & $0.6539 * * *$ & $0.6572 * * *$ & $0.6691 * * *$ \\
\hline Log gcf & & $0.1551 * * *$ & $0.1519 * * *$ & $0.1551 * * *$ & $0.1373 * * *$ & $0.1396^{* * *}$ & $0.1343^{* * * * *}$ \\
\hline Employment & & $0.0043 * * *$ & $0.0055 * * *$ & $0.0044 * * *$ & $0.0047 * * *$ & $0.0044 * * *$ & $0.0052 * * *$ \\
\hline$E d u$ & & $0.0104 * * *$ & $0.0082 * * *$ & $0.0109 * * *$ & $0.0062 * * *$ & $0.0061 * * *$ & $0.0051 * * *$ \\
\hline Log рори & & $0.9224 * * *$ & $0.9458 * * *$ & $0.9190 * * *$ & $0.6623 * * *$ & $0.6828 * * *$ & $0.6212 * * *$ \\
\hline Log ODA*trust & & & $0.0141 * * *$ & $0.0089^{* * *}$ & & & \\
\hline Democ & & & & & $0.0002 * * *$ & & \\
\hline $\log O D A^{*}$ democ & & & & & & $0.00003 * * *$ & $0.00003^{* * *}$ \\
\hline Arellano-Bond & $1^{\text {st }}$ order & $-2.2478 *$ & $-2.1647^{*}$ & -2.9171 & $-2.4269 *$ & $-2.3995^{*}$ & $-0.0179 * * *$ \\
\hline Autocor. test & $2^{\text {nd }}$ order & $-1.8521 * *$ & $-1.7874 * *$ & $-1.1069 * * * *$ & $-1.5201 * * *$ & $-1.5387 * * *$ & $-0.0234 * * *$ \\
\hline Sargan specification test & & 0.9 & 0.9 & 0.9 & 0.9 & 0.9 & 0.9 \\
\hline Total observations & & 218 & 218 & 218 & 256 & 256 & 256 \\
\hline
\end{tabular}

Source: Prepared by the authors.

Note: All variables except the inflation and interest rate variables are expressed in log form. $* * *$ Significant at $p$-value $<0.01$; $* *$ significant at $p<0.5 ; *$ significant at $p<0.1$. Arellano-Bond t-statistic means $\rho=0$.

ODA: Official development assistance.

Third, in line with previous results, models 4 to 6 show that ODA has a significant negative effect on growth, but this result turns positive and significant in countries with high levels of democracy. Specifically, these three models show that democracy on its own and the interaction term " $L o g \_O D A * d e m o c$ " have positive estimated coefficients. These findings are consistent with those of Burnside and Dollar (2000) and Collier and Dollar (2002), as the effect of ODA is positive in "good policy environments."
Fourth, and of no less importance than the previous results, when comparing columns 2 and 3 with columns 5 and 6 , we realize that the estimated coefficient for the interaction of trust and ODA is higher than the estimated coefficient for the interaction of democracy and ODA. This means that a trust-rich environment has a greater impact on the effectiveness of ODA in promoting growth than an environment with high levels of democracy. Therefore, donor agencies need to direct their efforts towards enhancing the capabilities of a larger proportion of the 
population rather than simply trying to replace primitive infrastructures with modern, technically sophisticated investments (Ostrom, 2000). If the local community is involved, the chances that ODA will be effective are greater. It is important for donors to gain a fuller understanding of the country's existing stock of social capital prior to developing policies or designing projects. Assessments of social capital could be combined with assessments of poverty and social policies and should be aimed at identifying institutions, social relationships and networks

\section{VI}

\section{Conclusions}

In this study, we have analysed the interaction among ODA, social capital and economic growth in order to investigate whether the effectiveness of development assistance in driving growth is conditional on the level of trust (a form of social capital) that exists in a recipient country. In line with similar findings presented in the literature, we have determined that the level of trust conditions the effectiveness of ODA in promoting growth: development assistance has a positive impact on growth in those countries where there is a significant level of trust and has a negative effect where trust is not present. Moreover, we have found that trust is a more important factor than democracy in heightening the effectiveness of ODA. In other words, a trust-rich environment has more of an impact on the effectiveness of ODA in leveraging growth than an environment that contribute to or impede growth and poverty alleviation (Grootaert, 1998).

Finally, a robustness analysis has been done in order to determine if the above results have been driven by just a few countries. The results were similar to those shown in table $2 .^{6}$

\footnotetext{
${ }^{6}$ Robustness results are available upon request.
}

with high levels of democracy has. Therefore, it is important for ODA investments to be directed towards those sectors that will further the development of social capital as a means of escaping poverty. It is also necessary to involve local communities more directly in order to attain the levels of trust required to make ODA more effective.

The presence of social capital, measured by trust, is important for growth and, when combined with ODA, can enhance its effectiveness. This is probably because trust facilitates cooperation among individuals by reducing transaction costs. However, an in-depth investigation of this aspect is beyond the scope of this study and would require an examination of the transmission mechanisms involved in the interaction between the existence of trust and growth based on ODA. 


\section{Bibliography}

Acemoglu, D. and others (2008), "Income and democracy", American Economic Review, vol. 98, No. 3, Nashville, Tennessee, American Economic Association.

Adler, P.S. and S.W. Kwon (2002), "Social capital: prospects for a new concept”, Academy of Management Review, vol. 27, No. 1, Briarcliff Manor, Academy of Management.

Arellano, M. and S. Bond (1991), "Some tests of specification for panel data: Monte Carlo evidence and an application of employment equations", Review of Economic Studies, vol. 58, No. 2, Oxford University Press.

Arndt, C., S. Jones and F. Tarp (2010), "Aid, growth and development: have we come full circle?", Journal of Globalization and Development, vol. 1, No. 2, De Gruyter.

Asiedu, E. and B. Nandwa (2007), "On the impact of foreign aid in education on growth: how relevant is the heterogeneity of aid flows and the heterogeneity of aid recipients?", Review of World Economics, vol. 143, No. 4, Springer.

Baliamoune-Lutz, M. and G. Mavrotas (2009), "Aid effectiveness: looking at the aid-social capital-growth nexus", Review of Development Economics, vol. 13, No. 3, Wiley.

Barro, R.J. and J. Lee (2012), "Full dataset [online] http://www. barrolee.com/data/full1.htm.

Bartolini, S. and L. Bonatti (2008), "Endogenous growth, decline in social capital and expansion of market activities", Journal of Economic Behavior \& Organization, vol. 67, No. 3-4, Amsterdam, Elsevier.

Beugelsdijk, S., H.L.F. de Groot and T. Van Schaik (2004), "Trust and economic growth: a robustness analysis", Oxford Economic Papers, vol. 56, No. 1, Oxford University Press.

Beugelsdijk, S. and T. Van Schaik (2005), "Social capital and growth in European regions: an empirical test", European Journal of Political Economy, vol. 21, No. 2, Amsterdam, Elsevier.

Bjørnskov, C. (2006), "The multiple facets of social capital", European Journal of Political Economy, vol. 22, No. 1, Amsterdam, Elsevier.

Boone, P. (1996), "Politics and the effectiveness of foreign aid", European Economic Review, vol. 40, No. 2, Amsterdam, Elsevier.

Bourdieu, P. (1986), "The forms of capital", Handbook of Theory and Research for the Sociology of Education, J. Richardson (ed.), New York, Greenwood.

(1985), "The social space and the genesis of groups", Theory and Society, vol. 14, No. 6, Springer.

Burnside, G. and D. Dollar (2000), "Aid, policies and growth", The American Economic Review, vol. 90, No. 4, Nashville, Tennessee, American Economic Association.

Chenery, H. and A. Strout (1966), "Foreign assistance and economic development", American Economic Review, vol. 56, No. 4, Nashville, Tennessee, American Economic Association.

Choritz, S. (2002), Literature Review of Evaluative Evidence on the Three Drivers of Effective Development: Ownership, Policy and Capacity Development, New York, United Nations Development Programme (UNDP).

Clemens, M.A. and others (2012), "Counting chickens when they hatch: timing and the effects of aid on growth", The Economic Journal, vol. 122, No. 561, Wiley.

Coleman, J. (2000), Foundations of Social Theory, Cambridge, Massachusetts, Belknap Press of Harvard University Press. (1988), "Social capital in the creation of human capital", American Journal of Sociology, vol. 94, Chicago, University of Chicago Press.

Collier, P. and A. Dollar (2002), "Aid allocation and poverty reduction", European Economic Review, vol. 46, No. 8, Amsterdam, Elsevier.

Dalgaard C.-J. and H. Hansen (2001), "On aid, growth and good policies", Journal of Development Studies, vol. 37, No. 6, Taylor \& Francis.

Djankov, S., J.G. Montalvo and M. Reynal-Querol (2008), "The curse of aid", Journal Economic Growth, vol. 13, No. 3, Springer.
(2006), "Does foreign aid help?", CATO Journal, vol. 26, No. 1, Washington, D.C., CATO Institute.

Dollar, D. and A. Kraay (2002), "Growth is good for the poor", Journal of Economic Growth, vol. 7, No. 3, Springer.

Dollar, D. and L. Pritchett (1998), Assessing Aid -What Works, What Doesn't, and Why, New York, Oxford University Press.

Doucouliagos, H. and M. Paldam (2011), "The ineffectiveness of development aid on growth: an update", European Journal of Political Economy, vol. 27, No. 2, Amsterdam, Elsevier.

Durlauf, S.N. (2002), "On the empirics of social capital", The Economic Journal, vol. 112, No. 483, Royal Economic Society.

Easterly, W. (2008), Reinventing Foreign Aid, Cambridge, Massachusetts, The MIT Press.

(2003), “Can foreign aid buy growth?", Journal of Economic Perspectives, vol. 17, No. 3, Nashville, Tennessee, American Economic Association.

Easterly, W., R. Levine and D. Roodman (2004), "Aid, policies and growth: comment", American Economic Review, vol. 94, No. 3 , Nashville, Tennessee, American Economic Association.

ECLAC (Economic Commission for Latin America and the Caribbean) (2002), Social Panorama of Latin America 2001-2002 (LC/G.2183-P), Santiago.

Fukuyama, F. (2001), "Social capital, civil society and development", Third World Quarterly, vol. 22, No. 120, Taylor \& Francis.

(1999), Social Capital and Civil Society, George Mason University.

Gibson, C.C. and others (2009), The Samaritan's Dilemma, Oxford, Oxford University Press.

Grootaert, C. (1998), "Social capital: the missing link?", Social Capital Initiative Working Paper, No. 3, Washington, D.C., World Bank.

Hall, P. (1999), "Social capital in Britain", British Journal of Politics, vol. 29, No. 3, Cambridge University Press.

Hansen, H. and F. Tarp (2001), "Aid and growth regressions", Journal of Development Economics, vol. 64, No. 2, Amsterdam, Elsevier.

(2000), "Aid effectiveness disputed", Journal of International Development, vol. 12, No. 3, Wiley.

Helliwell, J.F. (1996), "Economic growth and social capital in Asia", NBER Working Paper, No. 5470, Cambridge, Massachusetts, National Bureau of Economic Research.

Helliwell, J.F. and R.D. Putnam (2000), "Economic growth and social capital in Italy", Social Capital: A Multifaceted Perspective, P. Dasgupta e I. Serageldin (eds.), Washington, D.C., World Bank.

Kaufmann, D., A. Kraay and P. Zoido-Lobatón (1999), "Aggregating governance indicators”, Policy Research Working Paper, No. 2195, Washington, D.C., World Bank.

Knack, S. (2001), "Aid dependence and the quality of governance: cross-country empirical tests", Southern Economic Journal, vol. 68, No. 2, Southern Economic Association.

Knack, S. and P. Keefer (1997), "Does social capital have an economic payoff? A cross-country investigation", Quarterly Journal of Economics, vol. 112, No. 4, Oxford University Press.

Knowles, S. (2007), "Social capital, egalitarianism and foreign aid allocations", Journal of International Development, vol. 19, No. 3, Wiley.

Latinobarómetro (2010) [online] http://www.latinobarometro.org/ latContents.jsp.y.

Lensink, R. and H. White (2001), "Are there negative returns to aid?", The Journal of Development Studies, vol. 37, No. 6, Taylor \& Francis.

Levy, V. (1988), "Aid and growth in Sub-Saharan Africa: the recent experience", European Economic Review, vol. 32, No. 9, Amsterdam, Elsevier.

Loury, G.C. (1977), "A dynamic theory of racial income difference", Women, Minorities and Employment Discrimination, P.A. Wallace and A.M. LaMond (eds.), Lexington, Lexington Books. 
Mekasha, T.J. and F. Tarp (2013), "Aid and growth: what meta-analysis reveals", The Journal of Development Studies, vol. 49, No. 4, Taylor \& Francis.

Mosley, P. (1980), "Aid, savings and growth revisited", Oxford Bulletin of Economics and Statistics, vol. 42, No. 2, Wiley.

Mosley, P., J. Hudson and S. Horrel (1987), "Aid, the public sector and the market in less developed economies", The Economic Journal, vol. 97.

Neira, I., E. Vázquez and M. Portela (2009), "An empirical analysis of social capital and economic growth in Europe (1980-2000)", Social Indicators Research, vol. 92, No. 1, Springer.

OECD (Organization for Economic Cooperation and Development) (2013), "DAC database" [online] http://www.oecd.org/dac/stats/ international-development-statistics.htm.

(2001), The Well-being of Nations. The Role of Human and Social Capital, Paris.

Oorschot, W. and W. Arts (2005), "The social capital of European welfare states: the crowding out hypothesis revisited", Journal of European Social Policy, vol. 15, No. 1, SAGE.

Ostrom, E. (2000), "Social capital. A fad or fundamental concept?", Social Capital: A Multifaceted Perspective, P. Dasgupta and I. Seragilden (ed.), Washington, D.C., World Bank.

Polity IV (2013) [online] http://www.systemicpeace.org/inscr/inscr.htm.

Putnam, R.D. (2000), Bowling Alone: The Collapse and Revival of American Community, New York, Simon \& Schuster.

(1995), "Bowling alone: America's declining social capital", Journal of Democracy, vol. 6, No. 1.

Putnam, R., R. Leonardi and R. Nanetti (1993), Making Democracy Work: Civic Traditions in Modern Italy, Princeton, Princenton University Press.
Rajan, R. and A. Subramanian (2008), "Aid and growth: what does the cross-country evidence really show?", The Review of Economics and Statistics, vol. 90, No. 4, Cambridge, Massachusetts, The мIт Press.

Rivera-Batiz, F. (2002), "Democracy, governance and economic growth: theory and evidence", Review of Development Economics, vol. 6, No. 2, Wiley.

Sachs, J. (2011), The End of Poverty: How Can we Make It Happen in our Lifetime, London, Penguin.

Sargan, J.D. (1958), "The estimaction of economic relationship using instrumental variables", Econometrica, vol. 26, No. 3, New York, The Econometric Society.

SCIG (Social Capital Interest Group) (1999), "Social Capital: A Position Paper" [online] http://www.ssc.msu.edu/*internat/ soccap/position.htm.

Simon F. and M. McGillivray (2003), "Aid and public sector borrowing in developing countries", Journal of International Development, vol. 15 , No. 8 , Wiley.

Tarp, F. (2006), "Aid and development", Swedish Economic Policy Review, vol. 13, No. 2, Government Offices of Sweden.

Temple, J. (2001), "Growth effects of education and social capital in the oECD countries." OECD Economic Studies, No. 33, Paris.

Whiteley, P. (2000), "Economic growth and social capital", Political Studies, vol. 48, No. 3, Wiley.

World Bank (2014), "World Development Indicators" [online] http:// data.worldbank.org/data-catalog/world-development-indicators.

(1998), "The initiative on defining, monitoring and measuring social capital", Social Capital Initiative Working Paper, No. 1 [online] http://siteresources.worldbank.org/INTSOCIALCAPITAL/ Resources/Social-Capital-Initiative-Working-Paper-Series/ SCI-WPS-01.pdf.

(1985), World Development Report 1985, Washington, D.C.

ANNEX A1

TABLE A1.1

Latin America (189 countries): variable list specification, 2001-2010

\begin{tabular}{lll}
\hline Variable Description & Units & Source \\
\hline Dependent variable: & & \\
Log GDP Log of real GDP, PPP (constant 2005) & International dollars & World Development Indicators \\
Explanatory variables: & &
\end{tabular}

(a) Persistence in economic growth over time

\begin{tabular}{|c|c|c|c|}
\hline $\log G D P_{i, t-1}$ & $\begin{array}{l}\text { Log of real GDP, PPP in the preceding year } \\
\text { (constant 2005) }\end{array}$ & International dollars & World Development Indicators \\
\hline \multicolumn{4}{|c|}{ (b) Main variables } \\
\hline $\log O D A$ & Log of total net oDA & International dollars & OECD (DAC database) \\
\hline Trust & Trust & Percentage of persons & Latinbarómetro \\
\hline \multicolumn{4}{|c|}{ (c) Control variables } \\
\hline$E d u$ & Total years of schooling & Years & Barro and Lee database \\
\hline Employment & Employment to population ratio (ages $15+$ ) & Percentage of persons & World Development Indicators \\
\hline $\log g c f$ & Log of gross capital formation & International dollars & World Development Indicators \\
\hline Log рори & Log of total population & Number of persons & World Development Indicators \\
\hline Democ & Democracy index & $0-10$ & Polity IV ${ }^{\mathrm{a}}$ \\
\hline
\end{tabular}

Source: Prepared by the authors.

Note: ODA: Official development assistance.

a Polity IV is a research project on global freedoms, but it is also one of the largest databases capturing the evolution of freedoms worldwide. 
TABLE A1.2

Descriptive statistics

\begin{tabular}{|c|c|c|c|c|c|c|c|c|}
\hline & $\log G D P$ & $\log O D A$ & Trust & $E d u$ & Employment & $\log g c f$ & Log рори & Democ \\
\hline Mean & 24.93 & 363.84 & 0.19 & 6.91 & 58.88 & 3.04 & 16.27 & 7.48 \\
\hline Median & 24.54 & 236.89 & 0.19 & 7.18 & 58.30 & 3.05 & 16.07 & 8.00 \\
\hline Maximum & 28.34 & 3231.14 & 0.44 & 9.74 & 73.10 & 3.73 & 19.11 & 10.00 \\
\hline Minimum & 21.27 & 1.28 & 0.02 & 3.27 & 43.20 & 2.40 & 13.50 & -88.00 \\
\hline Standard deviation & 1.61 & 376.97 & 0.08 & 1.59 & 58.88 & 3.04 & 1.25 & 6.23 \\
\hline
\end{tabular}

Source: Prepared by the authors.

TABLE A 1.3

\section{Correlation matrix}

\begin{tabular}{|c|c|c|c|c|c|c|c|c|}
\hline & $\log G D P$ & $\log g c f$ & Employment & $\log O D A$ & $\log$ рори & $E d u$ & Democ & Trust \\
\hline $\log G D P$ & 1.00 & -0.08 & -0.11 & -0.00 & 0.95 & 0.17 & -0.07 & -0.18 \\
\hline $\log g c f$ & -0.08 & 1.00 & -0.08 & 0.12 & -0.07 & -0.09 & -0.04 & -0.04 \\
\hline Employment & -0.11 & -0.08 & 1.00 & 0.35 & 0.03 & -0.15 & -0.12 & -0.14 \\
\hline $\log O D A$ & -0.00 & 0.12 & 0.35 & 1.00 & 0.24 & -0.38 & -0.12 & -0.17 \\
\hline Log рори & 0.95 & -0.07 & 0.03 & 0.24 & 1.00 & -0.03 & -0.11 & -0.25 \\
\hline$E d u$ & 0.17 & -0.09 & -0.15 & -0.38 & -0.03 & 1.00 & 0.05 & 0.04 \\
\hline Democ & -0.07 & -0.04 & -0.12 & -0.12 & -0.11 & 0.05 & 1.00 & 0.07 \\
\hline Trust & -0.18 & -0.04 & -0.14 & -0.17 & -0.25 & 0.04 & 0.07 & 1.00 \\
\hline
\end{tabular}

Source: Prepared by the authors. 